\title{
Distribution and genetic diversity of Spodoptera frugiperda J. E. Smith (Noctuidae: Lepidoptera) on maize in West Sumatra, Indonesia
}

\author{
NOVRI NELLY", HASMIANDY HAMID, EKA CANDRA LINA, YUNISMAN \\ Department of Plant Protection, Faculty of Agriculture, Andalas University. Jl. Unand, Campus Limau Manis, Padang 25165, West Sumatra, Indonesia. \\ Tel.: +62-751-72701, Fax.: +62-751-72702, "email: novrinelly@agr.unand.ac.id
}

Manuscript received: 4 February 2021. Revision accepted: 9 April 2021.

\begin{abstract}
Nelly N, Hamid H, Lina EC, Yunisman. 2021. Distribution and genetic diversity of Spodoptera frugiperda J. E. Smith (Noctuidae: Lepidoptera) on maize in West Sumatra, Indonesia. Biodiversitas 22: 2504-2511. Fall Armyworm (FAW), Spodoptera frugiperda is a major maize pest, reportedly entering West Sumatra, Indonesia in early 2019. After a year of its discovery, there has been no information on the distribution and genetic diversity of this pest. In the present study, research has been carried out to obtain reliable information on the spread, incidence, and genetic diversity of this pest during July-October 2020 at the maize production center of West Sumatra, Indonesia. Sampling was then carried out using the purposive random sampling method, on maize fields in 5 districts (West Pasaman, Padang Pariaman, Solok, Limapuluh Kota and, Tanah Datar). The sample plots were determined with a size of $1 \times 1 \mathrm{~m}^{2}$ to observe the population and incidence, meanwhile, the observations were recorded on the larvae number and the percentage damage. Each district location's genetic diversity was analyzed based on the mitochondrial cytochrome c oxidase subunit I (COI) gene nucleotide variations amplified with specific primers. The observations show that $S$. frugiperda had attacked all maize planting sites in West Sumatra with the attacks ranging percentage from 12.78 to $41.25 \%$ and an average larval population of $0.26-1.05$ larvae / 2 plants. The genetic diversity analysis results of the S. frugiperda West Sumatra population, on the phylogenetic tree, were divided into two groups, the first is group A which consisted of West Pasaman isolates, and Solok isolates. The second, Group B consisted of Padang Pariaman, Limapuluh Kota, and Tanah Datar isolates (The percentage genetic similirity 99.86-100\%). The S. frugiperda population genetics in West Sumatra are similar to those isolates from several other countries in the world.
\end{abstract}

Keywords: COI, molecular identification, pest invasion, phylogenetic tree

\section{INTRODUCTION}

Fall armyworm (FAW) or Spodoptera frugiperda (Noctuidae: Lepidoptera) is a major pest that attacks maize plants. It originated from tropical and subtropical regions of the American continent causing a high reduction in yield in many countries (Early et al. 2018). It has a high migration ability, therefore it spread to many countries in the world. Baloch et al. (2020) created a Fall armyworm distribution map in central Asia, using native event records, environmental variables, and estimated potential distribution of geographic's S. frugiperda in Central Asia. This species tends to migrate during winter and settled in areas with higher temperatures.

Goergen et al. (2016) reported that the fall armyworm had entered West Africa in early 2016, besides that FAW was reported by the FAO that from 2016 to 2017 it had begun to spread throughout the African continent. Also, this pest in July 2018 has been found in India (Sharanabasappa et al. 2018) and Yemen while at the end of 2018, it was reported in Bangladesh, Sri Lanka, and Thailand. Consequently, from mid-2019 to march, 2020 it was reported in Myanmar, China, Laos, Malaysia, Indonesia, Vietnam, Egypt, and the Republic of Korea, Japan, Australia, and Mauritania (FAO 2021). To ascertain the identity of this pest morphological or molecular techniques have to be carried out (Cock et al. 2017).
FAW was first discovered in West Pasaman District, West Sumatra Province of Indonesia in March 2019 (Nonci et al. 2019). However, In the same year, it was reported from several regions like Lampung Province, North Sumatera, and Java Island of this same country that maize crops had been affected by FAW. Maharani et al. (2019), analyzed that FAW attacks were found in West Java on maize fields with elevations up to 800 masl.

Currently, FAW was known to have spread to almost all regions in Indonesia. The level of FAW attack in each area is thought to be influenced by many factors. These factors include the growth phase of maize in the field. High damage occurred in the vegetative phase compared to the generative phase. Maize varieties resistant to this pest have not been reported in Indonesia. Furthermore, Nelly et al. (2021) also observed five varieties of the maize planted by farmers in West Pasaman District were found and these varieties were all affected by FAW.

The spread of FAW pests in maize planting sites is thought to have originated in one location in West Sumatra. West Pasaman District was the first location for this pest to be discovered and reported as its spread source. The rate of FAW attack in several locations is not only influenced by the growth phase factor but is also thought to be influenced by genetic differences. It is not yet known the genetic diversity of FAW originating from maize in West Sumatra. Research has been carried out to observe the level of FAW attack and population on maize, as well as studying the 
genetic diversity of FAW in the population of West Sumatra.

\section{MATERIALS AND METHODS}

\section{Study Site}

The current study was conducted from July to October 2020 at maize production centers in West Sumatra, Indonesia, likewise, observations were carried out on maize plantations in West Pasaman, Tanah Datar, Solok, Limapuluh Kota, and Padang Pariaman districts meanwhile S. frugiperda genetic analysis was carried out in Indonesian Genetics Science laboratory.

\section{Incidence, distribution, and symptoms Spodoptera frugiperda percentage attacks}

The incidence was recorded using the purposive random sampling method, meanwhile, the sample location was taken in the maize area that showed attack signs. Plots with a size of $1 \mathrm{x} 1$ meter, furthermore, 5 plots of samples were taken diagonally on one plot. In each district, 3 maize fields were selected, then observed symptoms, affected plants percentage, and larvae population in the sample plots. Genetic diversity observation was carried out by analyzing the larvae DNA collected from each sample location (Cock et al. 2017).

All symptomatic plants were examined, this was done on the affected part and the attack percentage was calculated. Furthermore, this aims in determining the distribution, population, and attack level observed in all sample locations of maize production centers in West Sumatra.

\section{Genetic diversity of Spodoptera frugiperda in West Sumatra}

FAW larvae samples were collected from maize plants at six maize fields in West Sumatra (isolates) and analyzed to determine their genetic diversity. Isolates originate and consist of: A: Padang Pariaman isolates; B: Limapuluh Kota; C: Tanah Datar; D: Pasaman; E: West Pasaman; F: Solok isolate. The $F A W$ genetic diversity in West Sumatra was analyzed based on nucleotide variability of mitochondrial cytochrome c oxidase subunit I (COI) gene. The materials used in this study were Zymo Research Tissue \& Insect DNA Miniprep Kit D6016 (Zymo Research, USA), Bioline My Taq HS Red Mix BIO 25048 (Bioline, USA), Toyobo KOD FX Neo KFX-201 (Toyobo, Japan), LCO1490 forward primer (GGTCAACAAATCA TAAAGATATTGG), HC02198 reverse primer (TAAACTTCAGGGTGACCAAAAAATCA), agarose gel (ThermoFisher Scientific, USA), TBE buffer (ThermoFisher Scientific, USA), and 100 bp DNA ladder (ThermoFisher Scientific, USA).

\section{Genomic DNA extraction}

Genomic DNA was extracted from the larva of $S$. frugiperda were Zymo Research Tissue \& Insect DNA Miniprep Kit D6016 (Zymo Research, USA). Genomic DNA extraction procedure following the manual protocol of Zymo Research Tissue \& Insect DNA Miniprep Kit.
Then, eluted genomic DNA was analyzed quantitively using a NanoDrop Spectrophotometer (ThermoFisher Scientific, USA) with $260 \mathrm{~nm}$ wavelength.

\section{COI gene amplification}

COI gene was amplified using universal primers namely LCO1490 forward primer (GGTCAACAAATCA TAAAGATATTGG) and HC02198 reverse primer (TAAACTTCAGGGTGACCAAAAAATCA). This primer pair was estimated to produce a $710 \mathrm{bp}$ PCR product (Folmer et al. 1994). Isolated genomic DNA from the larva of $S$. frugiperda was used as template DNA in PCR amplification. PCR master mix that was used in this study were Bioline My Taq HS Red Mix BIO 25048 (Bioline, USA), Toyobo KOD FX Neo KFX-201 (Toyobo, Japan). PCR product then visualized by electrophoresis with $1 \%$ agarose gel (ThermoFisher Scientific, USA). 100 bp DNA ladder (ThermoFisher Scientific, USA) was used as a DNA ruler.

\section{DNA sequencing and data analysis}

A single-band of PCR amplicons was then used as a template for DNA sequencing. DNA sequencing method used in this study was Sanger sequencing in $1^{\text {st }}$ Base, Singapore. The electropherogram of each sample was analyzed using BioEdit (Hall 1999). The contig was made from the forward primer's read sequences and reverse primer's read sequence. BLAST (https://blast.ncbi.nlm.nih.gov/Blast.cgi) was used to align the contig sequence from each sample with $S$. frugiperda sequences in the genebank. Sequences of the COI gene from 25 isolates of $S$. frugiperda were collected from the genebank. The 25 isolates came from any other country across the world. Sequences of COI gene from 6 isolates of S. frugiperda in West Sumatra and another 25 isolates were used to obtain a phylogenetic tree. The phylogenetic tree was constructed using MEGA X software (Kumar et al. 2018) with the neighbor-joining method.

\section{Data analysis}

Data were analyzed using Microsoft excel which was expressed in tables and graphs, meanwhile, genetic data were analyzed by PCR DNA and displayed in the phylogenetic tree form.

\section{RESULTS AND DISCUSSION}

\section{Distribution, symptoms, and Spodoptera frugiperda attack level}

The results showed almost all maize plants observed in West Sumatra indicated signs of being attacked by $S$. frugiperda. The pest distribution and population were found in all sample locations in West Sumatra (Figure 1), furthermore, $S$. frugiperda was reported to attack maize for the first time in West Pasaman District in March 2019.

The spread of S. frugiperda in West Sumatra is very rapid, as seen in Figure 1. whereas, all of these five locations have been attacked by this pest. Initially, the maize crop in the first location was reported to have been 
attacked. in West Pasaman District almost all cultivations have been affected by $S$. frugiperda. However, symptoms and S. frugiperda larvae were found in locations that are close or quite far from the initial attack location furthermore, these pests' presence on the field is very easy to recognize by their symptoms.
The symptoms of maize infected with $S$. frugiperda can be seen on the leaves and stems (Figures 2.A-B). Based on these symptoms, it can be deduced that the pest involved is $S$. frugiperda (fall armyworm). The larvae infest on the plant part and feed on the leaves which later perforate the maize stalks' base before developing into a pupa (Figure 2.C).

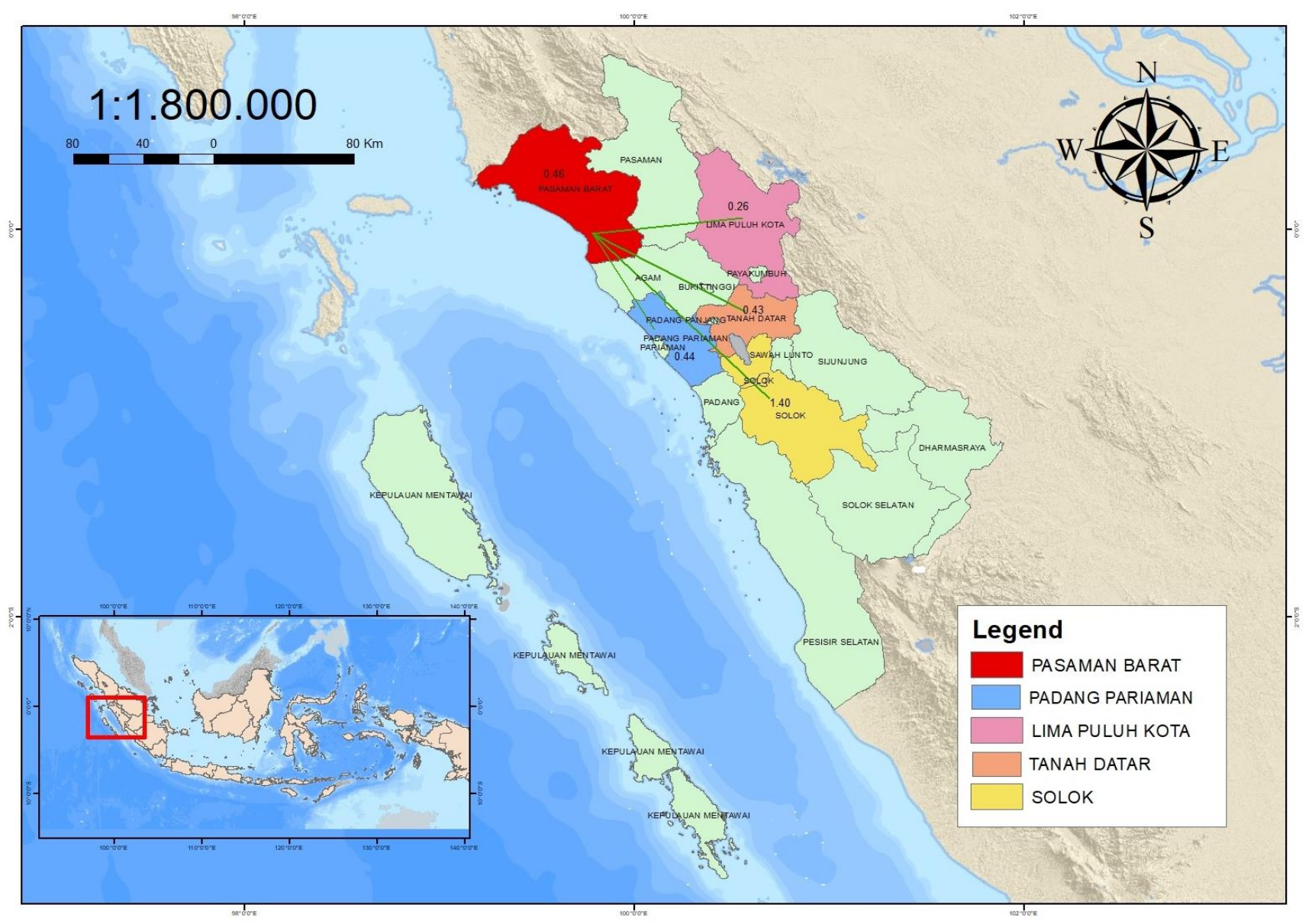

Figure 1. Distribution map of Spodoptera frugiperda from the initial location found to the maize area in West Sumatra, Indonesia

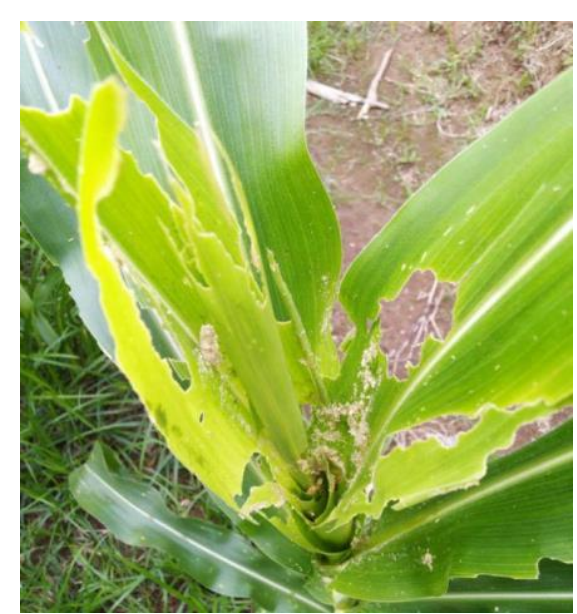

A

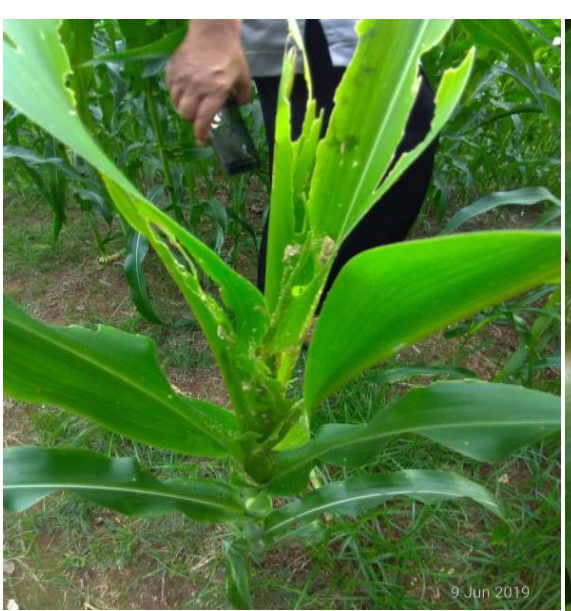

$\mathbf{B}$

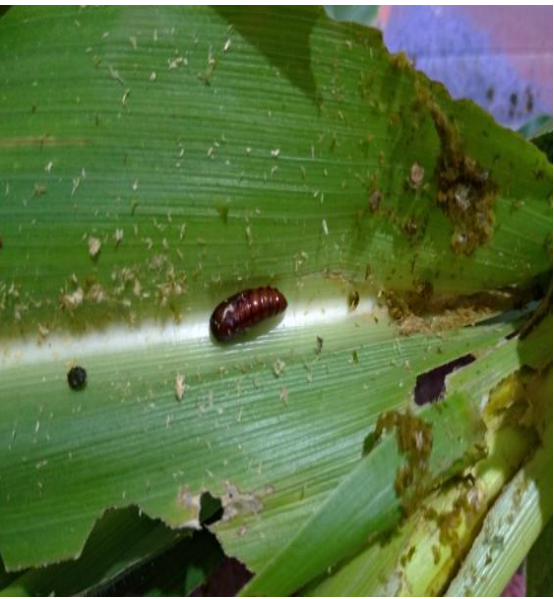

C

Figure 2. Spodoptera frugiperda symptoms attack on maize 
Maize plants affected by fall armyworm appear to be damaged or torn on leaves, especially young leaves. Damage caused to shoots, leaves, and stems base is very easy to recognize because the larvae secretion when dry looks like sawdust. The level of larval secretions on the maize is dependent on the number of larvae present in each stem. The larval population in maize is influenced by the total number of larvae and the phase of plant growth in the field. The infected maize stalks were found in 1,2 , or 3 larvae meanwhile the results per 2 stalks of maize were 0.48 on average and the highest larval population was 1.05 and the lowest was 0.26 larvae (Figure 3 ).

The $S$. frugiperda highest population larvae per 2 maize stalks were found in Solok District. Based on field observations, not all maize plants at each sample location were attacked by this pest. The larval population per sample plot and the larvae number in maize plants determine damage percentage in the field, meanwhile, the damaged highest percentage was found in Solok and Padang Pariaman Districts (Figure 4).

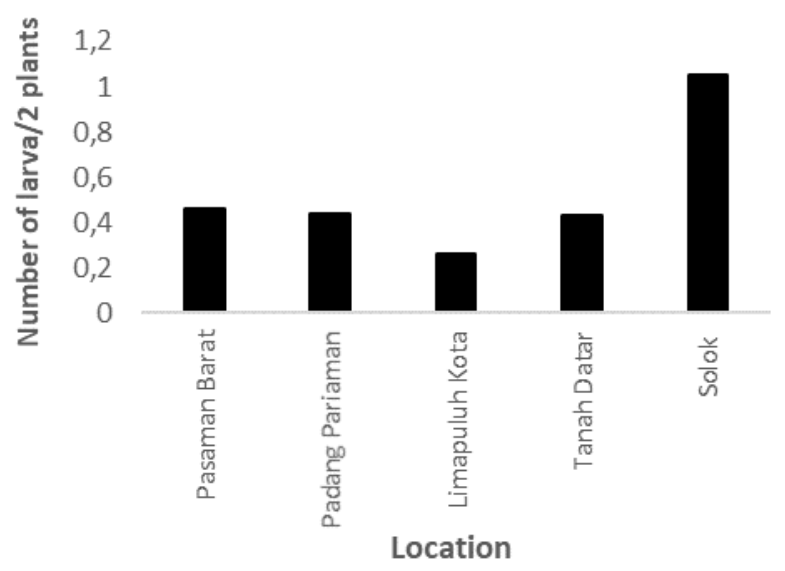

Figure 3. Larval population per 2 maize stalks in the distribution area in West Sumatra, Indonesia

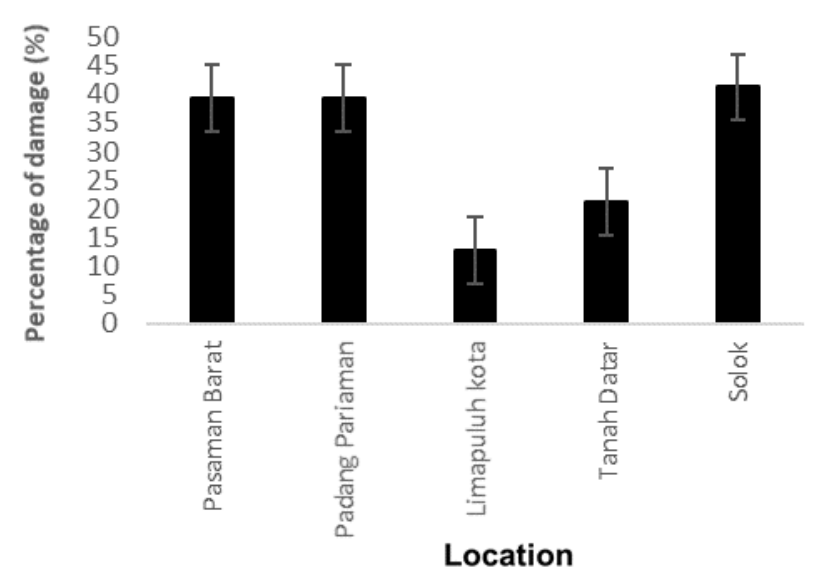

Figure 4. Damage percentage due to Spodoptera frugiperda attacks on maize planting sites in West Sumatra, Indonesia
Table 2. The concentration of Spodoptera frugiperda genomic DNA

\begin{tabular}{lcc}
\hline Isolate & $\begin{array}{c}\text { DNA } \\
\text { concentration } \\
(\mathbf{n g} / \mathbf{\mu L})\end{array}$ & $\mathbf{A ~ 2 6 0 / 2 8 0}$ \\
\hline Isolate Padang Pariaman & 65.7 & 2.19 \\
Isolate Limapuluh Kota & 48.7 & 2.19 \\
Isolate Tanah Datar & 93.6 & 2.17 \\
Isolate Pasaman Barat & 69.6 & 2.17 \\
Isolate Solok & 38.0 & 2.17 \\
\hline
\end{tabular}

The highest damage percentage was $41.25 \%$ in Solok district, followed by Padang Pariaman and West Pasaman. The attack high level was influenced by the $S$. frugiperda population in the field, meanwhile, the maize average population in Solok was more than 0.24 larvae per 2 plants with an average of 1.05 larvae. If the population is higher, the percentage of damage will also be high. The difference in population and attack level is thought to be related to differences in these insects' ability to invade.

Spodoptera frugiperda which invaded Indonesia has proven its very high migration capabilities. In West Sumatra, the population has spread to almost all of the maize fields. Larval populations varied widely in each location, where the highest is found in Solok District, followed by West Pasaman and Padang Pariaman. The attack symptoms and larvae morphology were the same in each population.

\section{Genetic diversity of $S$. frugiperda in West Sumatra population} Genomic DNA extraction from S. frugiperda larva

Genomic DNA from five isolates of $S$. frugiperda from West Sumatra was successfully being extracted. The concentration of genomic DNA from each isolate can be seen in Table 2.

From Table 2. above, we can see that genomic DNA from each isolates able to extract. The lower concentration of genomic DNA was found in isolate Solok $(38.0 \mathrm{ng} / \mu \mathrm{L})$ while the higher concentration was produce by isolate Tanah Datar (93.6 ng/ $\mu \mathrm{L})$. A260/280 ratio was used to detect the purification level of DNA. A 260/280 ratio of $\sim 1.8$ is generally accepted as "pure" for DNA (Wilfinger et al. 1997). From our study, the value of A 260/280 ratio from each sample ranges from 2.17 to 2.19 , which are higher than 1.8. So it means the genomic DNA extracted from five isolates of $S$. frugiperda larva is pure. The genomic DNA concentration of each isolate can be used for further analysis, which is PCR amplification. In PCR amplification, genomic DNA was used as template DNA, with a concentration of about $10 \mathrm{ng} / \mu \mathrm{L}$. So, the extracted genomic DNA from each isolate was then diluted into the final concentration of about $10 \mathrm{ng} / \mu \mathrm{L}$.

\section{COI gene amplification}

Mitochondrial cytochrome c oxidase subunit I (COI) gene is the most conservative protein-coding gene in the mitochondrial genome of animals. Folmer et al. (1994) were successful in designed a universal primer pair to 
amplify the COI gene in animals. The primers namely LCO1490 forward primer and HC02198 reverse primer. This primer pair was estimated to, that produce a $710 \mathrm{bp}$ PCR product. In our study, genomic DNA from five isolates of $S$. frugiperda also amplified using these primer pairs. The PCR amplicon product can be seen in the following Figure 5.

In figure 5, all samples produce a single, thick, and clear band as estimated at $710 \mathrm{bp}$ in length. These results indicate that the COI gene in five isolates of $S$. frugiperda from five locations in West Sumatra was successfully amplified. The PCR product was then used for sequencing analysis to determine the nucleotide sequences of the COI gene in each isolate. The genetic similarity index for West Sumatra isolates from 5 locations ranged from 99.86 to $100 \%$

\section{Phylogenetic relations of Spodoptera frugiperda}

The phylogenetic tree was constructed using MEGA X software (Kumar et al. 2018). The phylogenetic tree construction was obtained to study the relation of five isolates of $S$. frugiperda in West Sumatra with another $S$. frugiperda isolate across the world. Also, to predict the distribution pattern of $S$. frugiperda until reaches the West Sumatra region. The evolutionary history was inferred using the Neighbor-Joining method (Saitou and Nei 1987). The evolutionary distances were computed using the Kimura 2-parameter (Kimura 1980). The bootstrap tests were using 1000 replicates. Cut off value for consensus tree which was used about $50 \%$. The phylogenetic tree can be seen in the following Figure 6.

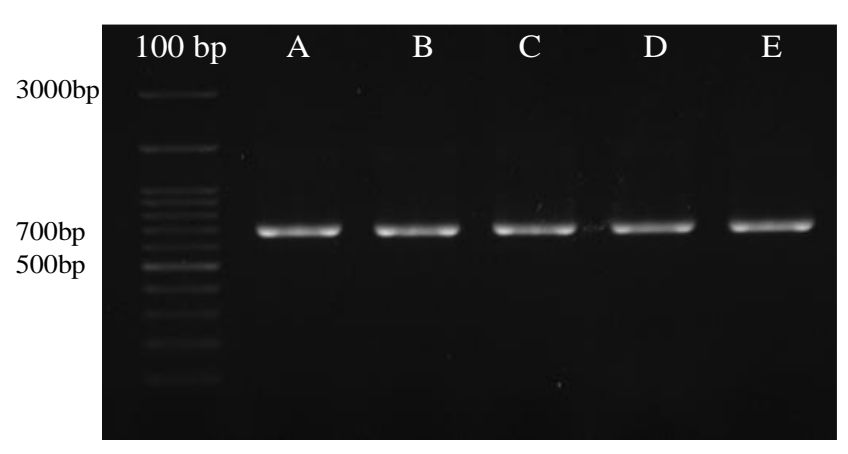

Figure 5. COI gene amplification product of five isolates of Spodoptera frugiperda. A. isolate Padang Pariaman, B. isolate Limapuluh Kota, C. isolate Tanah Datar, D. Pasaman Barat, E. isolate Solok

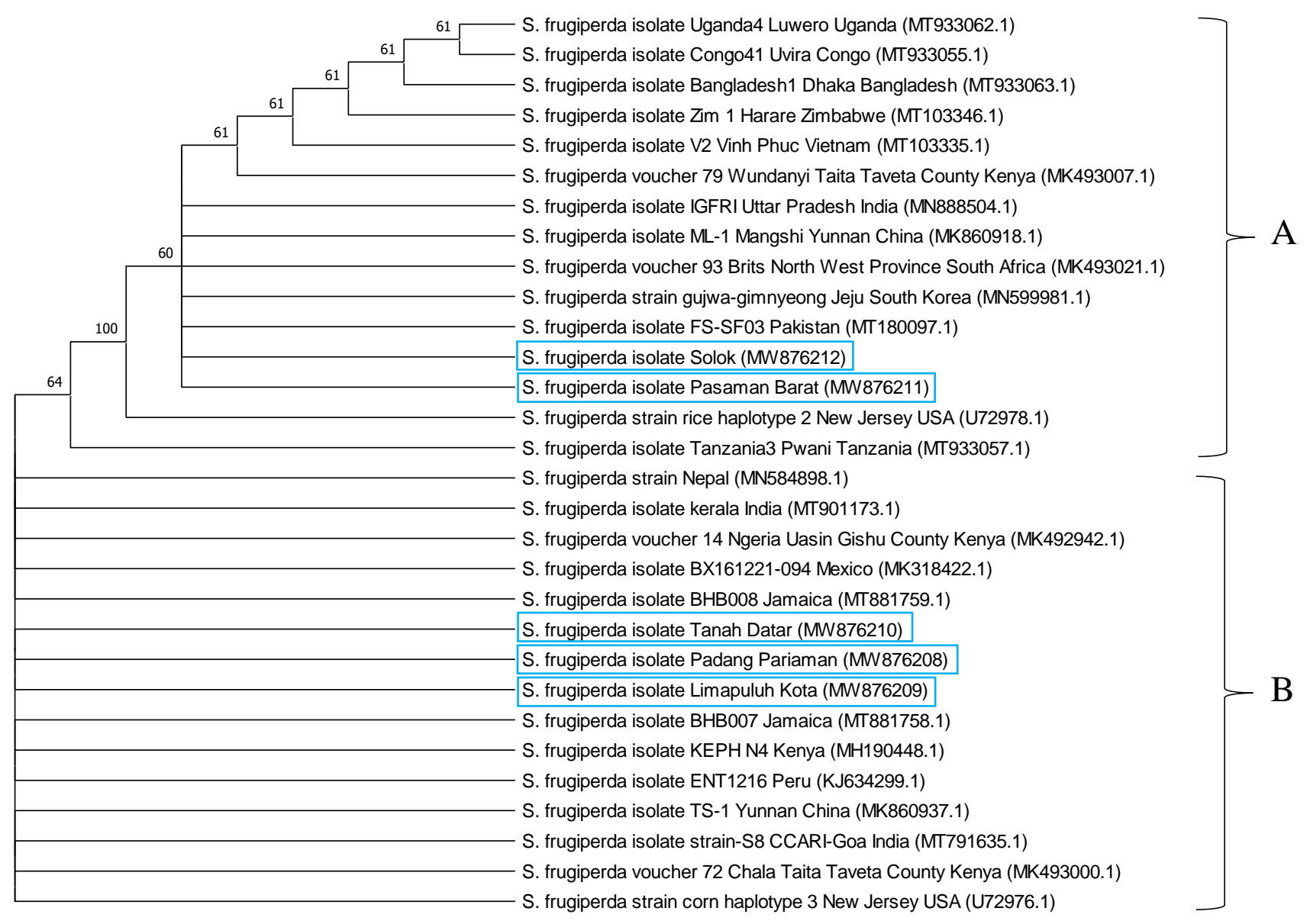

Figure 6. Phylogenetic tree of several isolates of Spodoptera frugiperda 
In Figure 6, it can be seen that in West Sumatra $S$ frugiperda population consists of 2 large groups. The first group (A) Solok and West Pasaman isolates were included in one group, meanwhile, the second group (B) consisted of Padang Pariaman, Limapuluh Kota, and Tanah Datar isolates. Isolates are larvae found and collected from maize plantations in the sample locations. S. frugiperda larvae from different districts but close to each other, such as Padang Pariaman, Limapuluh Kota, and Tanah Datar show the same genetic diversity. Furthermore, S. frugiperda genetic diversity is thought to also affect many things such as the ability to develop or population growth and attack on the host.

\section{Discussion}

Spodoptera frugiperda attacked maize crops and the first reported attack was in West Pasaman District and West Sumatra Province. This pest is thought to have entered and spread to many locations in Indonesia. After more than one year, it is reported that $S$. frugiperda has spread to all regions in West Sumatra in particular, and Indonesia in general. Initially, the FAO (2020) reported that $S$. frugiperda attacks had occurred in various countries in the world such as in Africa and Asia, meanwhile, in early 2016 it was reported that this pest had been found in West Africa. In two years, S. frugiperda has spread to 44 countries in Africa and this pest was also found in 2018 in India and spread to all maize growing locations in India. Early 2019, S. frugiperda had invaded Yunan China, and within 10 months it had spread to all maize crops in China (Baloch et al. 2020) furthermore, in 2019, it was also reported that $S$. frugiperda had entered Myanmar, Thailand, and other Asian countries. Huang et al. (2020), make spread pest predictions in Central Asia and China in particular. S. frugiperda tends to migrate in areas with higher temperatures, causing losses to maize crops. The maize planting condition in Indonesia with high environmental temperatures is thought to be suitable for this pest development.

Almost all maize plantations in West Sumatra Province, especially the early growth phase, have shown Fall armyworm symptoms. This pest attacks the base and the leaves stem. Moreover, the FAW symptoms of an attack are very easy to notice in maize and are often caused by larvae (Figure 1). The population per 2 stems was calculated and compared with the economic threshold of the other genus Spodoptera, but no economic threshold calculation for $S$. frugiperda has been reported. Therefore, as a comparison to an economic threshold and the S. litura economic threshold value is 0.24 larvae per 2 soybean plant stalks (Arifin and Oka 1993).

The $S$. frugiperda highest average population per 2 maize stalks was found in Solok District with 1.05 larvae. When compared with the $S$. litura economic threshold which is 0.24 larvae / 2 stems, furthermore in all areas the $S$. frugiperda population is above the economic threshold. The lowest population was in Limapuluh Kota district, with 0.26 larvae / 2 sticks. The population in the initial attack area was also high, with 0.46 larvae / 2 stems, meanwhile, the population level in West Pasaman was not too different from Padang Pariaman District, with 0.44 larvae (Figure 2). The $S$. frugiperda average population larvae are above the economic threshold. A high pest population usually causes a high attack level.

The $S$. frugiperda attacks percentage in all observed locations shows a difference the highest in Solok District. In comparison with the larval population, the higher the population, the higher the percentage rate of affected plants. Attacks in Solok, Padang Pariaman, and West Pasaman districts tended to be higher than those in Tanah Datar and Limapuluh Kota districts. The pest infestation high rate is suspected to have always been the availability of maize plants in the field. According to Subiono (2020), maize plants are the most preferred host for S. frugiperda. Maize, rice, and baciaria grass plants were consumed higher than soybeans and peanuts. There have been no reports of $S$. frugiperda attacking crops other than maize in West Sumatra and this pest is polyphagous, however, at the observation site, it was only found in maize with a different population.

There are differences in population abundance and the pest attack level in the field, this is presumably due to the $S$. frugiperda genetic diversity that has spread in all maize planting locations. The observed results from the $S$. frugiperda genetic diversity in the West Sumatra population showed that there were 2 genetic groups, including Group A. West Pasaman,and Solok. Group B consisted of isolates from Tanah Datar, Limapuluh Kota, and Padang Pariaman.

Based on phylogenetic tree performance, isolate West Pasaman included in group A together with isolate V2 from Vinh Phuc, Vietnam (MT103335.1). Which is Vietnam is the closest country to West Pasaman District based on geographical location. But, West Pasaman District is far from Solok District. Lima Puluh Kota District, Tanah Datar District, and Padang Pariaman District are located in the middle between West Pasaman District and Solok District.

While the three isolates from West Sumatra located in group B were isolated Limapuluh Kota, isolate Padang Pariaman, and isolate Tanah Datar. Based on geographical location, Limapuluh Kota District, Padang Pariaman District, and Tanah Datar District are also located side by side. The closest isolate in the phylogenetic tree from these three isolates is two isolates from Jamaica namely isolate BHB008 (MT881759.1) and BHB007 (MT881758.1).

Spodoptera frugiperda was firstly reported in the USA. The two isolates namely $S$. frugiperda strain corn haplotype 3 New Jersey (U72976.1) and strain rice haplotype 2 New Jersey (U72978.1). In our phylogenetic tree, two early reported isolates from New Jersey, USA is located in the different group. S. frugiperda strain rice haplotype 2 New Jersey (U72978.1) is grouped in group A along with isolate from West Pasaman and Solok. While $S$. frugiperda strain corn haplotype 3 New Jersey (U72976.1) is grouped in group B along with isolate from Lima Puluh Kota, Tanah Datar, and Padang Pariaman Districts.

Viewed from the world distribution map, the population originates from the Americas and spreads to the African 
continent, and then enters Indonesia in early 2019. There are differences in genetic DNA, presumably due to pest adaptation in the field. Likewise, the identification carried out by Lestari et al. (2020), the genetic found in Lampung Indonesia is $S$. frugiperda. There was no nucleotides variation in the sequence of COI gene among S. frugiperda found in Lampung Province.

Besides, the $S$. frugiperda gene Identification is necessary for control purposes and the presence of the different strains requires different handling methods. At different locations, different strains can be found, therefore the management techniques are also different. The control techniques developed in several countries have been developed by researchers. These techniques need to be adapted in each condition and location, such as in Africa, the control methods tested are with intercropping and companion cropping systems, 'climate-adapted push-pull'. This method is effective in reducing the population of $S$. frugiperda larvae and has been adopted by local farmers (Midegaa et al. 2018).

Furthermore, In Indonesia, it is also necessary to study effective and efficient control techniques. After conducting observations in several maize planting locations, which consists of 5 districts as samples. $S$. frugiperda was always found and this pest has been found to have spread from the first location of origin (West Pasaman) to maize plantations in all observed locations in West Sumatra.

The damage percentage ranged from 12.78 to $41.25 \%$, meanwhile, the average larva population was $0.26-1.05$ larvae/2 stalks of maize. The genetic diversity analysis results of $S$. frugiperda in the West Sumatra population were described by the phylogenetic tree and $S$. frugiperda genetics were divided into two groups, group A, which consisted of West Pasaman and Solok isolates while group B consisted of Padang Pariaman, Limapuluh Kota, and Tanah Datar isolate. The genetic $S$. frugiperda population of West Sumatra has similarities with the genetics of isolates from several other countries in the world.

\section{ACKNOWLEDGEMENTS}

We gratitude and appreciate to Rector of Universitas Andalas, Padang, Indonesia who funded this study with Research Professor Cluster: No. T/13/UN.16.17/ PP. Pangan-KRP1GB/ LPPM/ 2020 on behalf of the first author (Novri Nelly). Thanks to Maythesya Oktavioni for supporting the analysis of genetic data.

\section{REFERENCES}

Arifin M, Oka IIN. 1993. Economic Thresholds and Sampling Techniques for Armyworm Populations: Spodoptera litura (F.) in Soybean Plants. [Dissertation]. University of Gadjah Mada, Yogyakarta. [Indonesian]

Baloch MN, Fan J, Haseeb M, Zhang R. 2020. Mapping potential distribution of Spodoptera frugiperda (Lepidoptera: Noctuidae) in Central Asia. J Insects 11 (3): 172-181. DOI 10.3390/insects11030172.
Cock MJ, Beseh PK, Buddie AG, Cafá G, Crozier J. 2017. Molecular methods to detect Spodoptera frugiperda in Ghana, and implications for monitoring the spread of invasive species in developing countries. Sci Rep 7 (1): 1-10. DOI: 10.1038/s41598-017-04238-y.

Early R, Gonzalez-Moreno P, Murphy ST, Day R. 2018. Forecasting the global extent of invasion of the cereal pest Spodoptera frugiperda, the fall armyworm. J NeoBiota 40: 25-50. DOI: 10.3897/neobiota.40.28165.

Folmer O, Black M, Hoeh W, Lutz R, Vrijenhoek R. 1994. DNA primers for amplification of mitochondrial cytochrome c oxidase subunit I from diverse metazoan invertebrates. Mol Mar Biotechnol 3 (5): 294299.

Food and Agriculture Organization (FAO). 2020. Global Monitoring for Fall Armyworm Control. http://www.fao.org/fallarmyworm/monitoring-tools/faw-map/en/ [January, 17. 2021]

Goergen G, Kumar PL, Sankung SB, Togola A, Tamò M. 2016. First report of outbreaks of the fall armyworm Spodoptera frugiperda (JE Smith) (Lepidoptera, Noctuidae), a new alien invasive pest in West and Central Africa. PloS ONE 11 (10): e0165632. DOI: 10.1371/journal.pone.0165632.

Hall TA. 1999. BioEdit: A user-friendly biological sequence alignment editor and analysis program for windows 95/98/NT. Nucleic Acids Symp Ser 41: 95-98.

Huang Y, Dong Y, Huang W, Ren B, Deng Q, Shi Y, Bai J, Ren Y, Geng Y, Ma H. 2020. Overwintering distribution of fall armyworm (Spodoptera frugiperda) in Yunnan, China, and influencing environmental factors. J Insects 11 (11): 805-818. DOI: 10.3390/insects11110805.

Kimura M. 1980. A simple method for estimating the evolutionary rate of base substitutions through comparative studies of nucleotide sequences. J Mol Evol 16:111-120. DOI: 10.1007/BF01731581.

Kumar S, Stecher G, Li M, Knyaz C, Tamura K. 2018. MEGA X: Molecular evolutionary genetics analysis across computing platforms. Mol Biol Evol 35: 1547-1549. DOI: 10.1093/molbev/msy096.

Lestari P, Budiarti A, Fitriana Y, Susilo FX, Swibawa IG, Sudarsono H, Suhardjo R, Hariri AM, Purnomo, Nuryasin, Solikhin, Wibowo L, Jumari, Hartaman M. 2020. Identification and genetic diversity of Spodoptera frugiperda in Lampung Province, Indonesia. Biodiversitas 21 (4): 1670-1677. DOI: 10.13057/biodiv/d210448

Maharani Y, Dewi VK, Puspasari LT, Rizkie L, Hidayat Y, Dono D. 2019. Cases of fall armyworm Spodoptera frugiperda J. E. Smith (Lepidoptera: Noctuidae) attack on maize in Bandung, Garut, and Sumedang district, West Java. Cropsaver 2 (1): 38-46. DOI: 10.24198/cropsaver.v2i1.23013.

Midegaa CAO, Pittchara JO, Pickettb JA, Hailua GW, Khana ZR. 2018. A climate-adapted push-pull system effectively controls fall armyworm, Spodoptera frugiperda (J. E. Smith), in maize in East Africa. J Crop Prot 105:10-15. DOI: 10.1016/j.cropro.2017.11.003.

Nelly N. Hamid H, Lina EC, Yunisman. 2021. The use of several maize varieties by farmers and the infestation of Spodoptera frugiperda (Noctuidae: Lepidoptera). IOP Conf Ser Earth Environ Sci 662: 012020. DOI: 10.1088/1755-1315/662/1/012020.

Nonci N, Kalqutny SH, Mirsam H, Muis A, Azrai M, Aqil M. 2019. Introduction of Fall Armyworm (Spodoptera frugiperda J. E. Smith) New Pests on Maize Plants in Indonesia. Ministry of Agriculture, Agricultural Research and Development Agency for Cereal Crops Research, Jakarta. [Indonesian]

Saitou N, Nei M. 1987. The neighbor-joining method: A new method for reconstructing phylogenetic trees. Mol Biol Evol 4: 406-425. DOI: 10.1093/oxfordjournals.molbev.a040454.

Sharanabasappa, Kalleshwaraswamy CM, Asokan R, Mahadeva-Swamy HM, Maruthi MS, Pavithra HB, Hedge K, Navi S, Prabhu ST, Goergen G. 2018. First report of the fall armyworm Spodoptera frugiperda (JE Smith) (Lepidoptera: Noctuidae) an alien invasive pest on maize in India. Pest Manag Hortic Ecosyst 24 (1): 23-29.

Subiono T. 2020. Preferences of Spodoptera frugiperda (Lepidoptera: Noctuidae) in several feed sources. Jurnal Agroekoteknologi Tropika Lembab 2: 130-134. DOI: 10.35941/jatl.2.2.2020.2813.130-134. [Indonesian]

Wilfinger WW, Mackey K, Chomczynski P. 1997. Effect of pH and ionic strength on the spectrophotometric assessment of nucleic acid purity. BioTechniques 22: 474-481. DOI: 10.2144/97223st01. 